\title{
Using iPads as the Digital Tool to Integrate Authentic Assignments into a Teacher Preparation Program
}

\author{
Nanette Edeiken Cooperman ${ }^{1}$ \\ ${ }^{1}$ Department of Special Education, Saint Joseph's University, Philadelphia, USA \\ Correspondence: Nanette Edeiken Cooperman, Assistant Professor, Department of Special Education, Saint Joseph's \\ University, 5600 City Ave., Philadelphia, PA 19131, USA.
}

Received: July 19, 2016

doi:10.5430/irhe.v1n2p174
Accepted: July 26, 2016

Online Published: August 3, 2016

URL: http://dx.doi.org/10.5430/irhe.v1n2p174

\begin{abstract}
The purpose of this study was to address the question as to how teacher preparation programs can modify their curriculum to include authentic experiences with the integration of technology that will support the teaching and learning practices of special education teacher candidates. Additionally, this study investigated whether the inclusion of authentic assignments would facilitate the transfer of skills and knowledge of teacher candidates to teaching practices and reduce the disconnect between what strategies are used in special education teacher preparation programs and those strategies that special education teachers are using in the classroom.
\end{abstract}

Keywords: authentic assignments, special education, digital tools, teacher preparation

\section{Introduction}

The challenge in higher education teacher preparation programs is to prepare our candidates to become highly qualified teachers and to understand how to transfer their learned knowledge of theory to practice. Too often we find that there is a knowledge gap between what pre-service teachers or teacher candidates are learning in the classroom and what curriculum our teachers are implementing in their schools. In an effort to reduce this knowledge gap our goal should be to integrate authentic experiences and activities into our teacher training programs in an attempt to provide ease of transferring this knowledge to the community of practice. According to Iverson, Lewis, and Talbot (2008), "increased authenticity of activities, tasks and assessments will improve teacher education programs and, consequently, teacher candidates' learning experiences" (p. 291).

Defining authenticity and determining the essential components of an authentic task is central to changing the delivery of course work and assessment in higher education. A crucial component of authentic assignments should be to focus on methods of curriculum that are used by educators in the field. Although a teacher candidate may have grasped theoretical knowledge, this does not ensure that they will be successful when implementing this practice in the field. It is for this reason that educational researchers promote the use of authentic assignments that are representative of those evidence-based practices currently in use (Darling-Hammond, Ancess, \& Falk, 1995; Wiggins, 1999; Newmann, Secada, \& Wehlage, 1995; Iverson, et al., 2008). According to Neumann, Secada, and Wehlage (1995), authentic tasks should "address a concept, problem or issue that is similar to one that they have encountered or are likely to encounter in life beyond the classroom" (p. 24). If this is accomplished, the result should provide context to theory and practice and increase the teacher candidates' ability to apply theory to pedagogical situations experienced in the field (Iverson et al., 2008).

In addition to authentic assignments, preparing special education teacher candidates to have an understanding as to how to integrate technology into their teaching practice has become a necessity primarily because of the mandates set forth in federal law. The Individuals with Disabilities Education Improvement Act (IDEIA, 2004) requires educational and child study teams serving individuals with disabilities to consider assistive technology devices to support educational programming [20 U.S.C. $1401 \S 614(\mathrm{~B})(\mathrm{v})]$. They further define an assistive technology (AT) device as "any item, piece of equipment, or product system, whether acquired commercially off the shelf, modified, or customized, that is used to increase, maintain, or improve the functional capabilities of a child with a disability" [20 U.S.C.1401§602(1)]. Therefore, the added dimension of integrating technology into the authentic assignments using evidence-based practices should also be required of the teacher candidates. Laarhoven and Conderman (2011) stated the following: 
Teachers, particularly special educators, must a) be aware of available technologies, b) select devices or programs that can increase the performance and functioning of their students, c) assist students with using technologies and evaluating their effectiveness in instructional environments, d) effectively integrate technologies into instruction to ensure improved learner performance. (p. 474)

This combination should provide meaningful experiences to future teaching practices by equipping the teacher candidates with the ability to conceptualize the connections between current digital tools and their appropriate use in the classroom (Vannatta \& Beyerbach, 2000). According to Zhao (2003) “...for teachers to use technology, they need to develop knowledge that enables them to transfer technological potentials into solutions to pedagogical problems" (p. 4). The alignment between the technology topics presented to the teacher candidates and those in use in the classroom to support teaching and learning should contribute to reducing the aforementioned knowledge gap (Ottenbreit-Leftwich et al., 2012).

The purpose of this study was to begin to address the question as to how teacher preparation programs can modify their curriculum to include authentic experiences with the integration of technology that will support the teaching and learning practices of special education teacher candidates. In this particular situation authenticity referred to activities or projects that paralleled or represented professional tasks that are performed in the field in order to satisfy the individual needs of students with disabilities. Additionally, this study investigated whether the inclusion of authentic assignments would facilitate the transfer of skills and knowledge of teacher candidates to teaching practices and therefore reduce the disconnect between what strategies are used in special education teacher preparation programs and those strategies that special education teachers are using in the classroom.

\section{Method}

\subsection{Research Question \#1}

How can we modify our curriculum in special education teacher preparation programs to include authentic learning opportunities with the integration of technology that can bridge the gap between the higher education classroom and pedagogical situations experienced in the field?

\subsection{Research Question \#2}

Do special education teacher candidates perceive that authentic assignments with the integration of technology will assist them in applying theory to pedagogical situations experienced in the field?

The research questions were addressed through a qualitative research design that involved two stages. In the first phase of the study the curriculum of one university level course entitled Educating Students with Low Incidence Disabilities was modified to include assignments that were determined to be authentic through a review of best practices and included the integration of the use of an iPad as the digital tool. Students completed their assignments in small groups using apps that were chosen by the professor because of their use in the field and uploaded to the iPad by the technology department at the University. At the end of the semester all students were encouraged to voluntarily complete a survey to express their opinion in reference to Research Question \#1.

The second phase of the study was accomplished through the use of a semi-structured focus-group interview with representative teacher candidates from the special education class in the the teacher preparation program. This interview process was completed in order to evaluate the learning experience of the teacher candidates through the use of authentic assignments with the integration of technology in the university classroom. Their beliefs as to whether this reduced the knowledge gap between theory and practical application of that theory, or Research Question \#2, were also explored.

\subsection{Participants}

A total of 31 undergraduate students enrolled in the Special Education class entitled Educating Students with Low Incidence Disabilities were required to participate in phase one of this qualitative study. At the time of the study the students were all second semester juniors, all were female, and they were all double majors working towards Elementary Education, PK-4, and Special Education, PK-8, certification in the state of Pennsylvania. All of the students were preparing to student teach in the following academic year in both an elementary education classroom as well as a special education classroom with students who had been diagnosed with either high or low incidence disabilities. Participation in the subsequent survey and interview was voluntary.

\subsection{Procedures}

The first phase of this study involved a review of the curriculum for this specific course to determine what assignments could be modified to be considered authentic and to have the flexibility to integrate technology into the 
assignment. The university professor designed and developed the assignments that previously were completed using fictitious case studies and paper and pencil methodologies. The goal was to adapt these assignments in order to develop authentic tasks and, as stated by Iverson et al. (2008), to be "representative of professional practice" and to require "a degree of thought and attention that can push students to higher levels of understanding" (p. 295). The first assignment chosen involved the development and implementation of a story based intervention based on a skill that was determined to be appropriate for one of the students from the teacher candidate's field experience and in consultation with the cooperating teacher at the field school. The skills varied dependent on the needs of the student but included self-help skills, i.e., eating, dressing, skills required to travel in the community, transition skills, and functional academic skills. The second assignment chosen involved the development and implementation of a Picture Exchange Communication System (PECS) that was determined to be appropriate for one of the students from the teacher candidate's field experience and in consultation with the cooperating teacher at the field school. The PECS included language related to choosing an item to eat, choosing a positive reinforcement, picture schedules, and basic language skills. An iPad that was supplied by the University and loaned to the student for the entire semester was used as the source for the final outcome and an Apple TV was used for the presentation to the other teacher candidates enrolled in the course.

A survey was developed with 27 questions that included multi-part opinion questions, demographic questions, and open ended questions to be completed at the end of the semester (Appendix 1). Participation was voluntary and 19 of the 31 students enrolled in this course who completed the assignments chose to participate in the survey. The survey was formatted in Qualtrics and Survey Monkey and all of the 19 participating students completed both formats.

The second phase of the study was a focus group that was comprised of four of the teacher candidates who were enrolled in the University class that participated in this study. Circular seating was arranged in order to facilitate spontaneous responses and an interchange between those in the group (Krathwohl, 2009). The interview was semi-structured and a nondirective approach was used in an attempt to encourage the members of the focus group to describe what they experienced through descriptions of specific situations and actions (Brinkmann \& Kvale, 2015). An interview guide (Appendix 2) was used that contained topics and suggested questions. The intention was to allow the conversation to flow from the questions dependent on the responses of the students. The purpose of the interview was explained to the participants prior to beginning and the interview was videotaped with the signed permission of each individual.

\subsection{Data Analysis}

A qualitative analysis was utilized to determine the results of this study. Relationships in the data were determined by systematically comparing responses of the informants in the interviews and the surveys. Coding was data-driven implying that no codes were developed in advance of the data collection process (Brinkmann \& Kvale, 2015).

The survey questions were completed in both Qualtrics and Survey Monkey in order to determine the most effective method of analyzing the results of the survey and to determine reliability of the survey questions. Construct validity was determined through a review of the survey questions by another expert in the field to determine if the questions were asking what the survey intended to measure. The researcher then analyzed the results using a word cloud to determine code categories as well as line and bar graphs to determine relationships that were created from the teacher candidates' responses. The use of computer software provided the capability to determine relationships through graphic representations of codes, to automatically code where certain phrases or words appeared, and to link information for coding (Krathwohl, 2009).

The focus group was video-taped and analyzed in order to determine recurring codes or themes. Words and phrases were organized into coding categories. According to Bogdan and Biklen (2007), "As you read through your data, certain words, phrases, patterns of behavior, subjects' ways of thinking, and events repeat and stand out" and become coding categories (p. 173). The initial codes were reorganized, reanalyzed, and refined into related categories. The results were then member checked for accuracy and validity. Outcomes were shared with the participants in an effort to "retain coherence with the views of the informants" (Brenner, 2006, p. 368).

\section{Results}

The students provided demographic data that indicated that all of the participants were female, second semester juniors, and all were preparing to student teach in order to receive their certification in both Elementary Education (PK-4) and Special Education (PK-8) during the following academic year. The students were not required to indicate their overall GPA, but it is a requirement in the State of Pennsylvania where this university is located to have a 
minimum GPA of 3.0 in order to be accepted into the initial teacher certification program, student teach, and receive teacher certification.

The three core concepts or themes that were identified through coding of both the focus group and the survey data were authenticity of learning opportunities, technology, and feedback. Presented below is a discussion of the three identified themes.

\subsection{Authenticity/Technology}

In this study authenticity, as defined by the professor/researcher, referred to activities or projects that paralleled or represented professional tasks that are performed in the field in order to satisfy the individual needs of students with disabilities. The two codes of authenticity and technology are being combined in this discussion because Research Question \#1 specifically referenced the perception of authentic assignments with the integration of technology.

The participants were asked explicit questions in both the survey and the focus group interview in reference to whether the newly developed assignments enhanced their learning experience and if they believed they were more engaged in the course and the information presented when completing assignments with the integration of technology. The responses were overwhelmingly positive in relationship to the curriculum changes (Figure 1). The teacher candidates stated in open ended questions that they completed assignments with "realistic situations" and that they "were able to use apps that we can actually use in the future." They referenced the assignments as being "authentic" and stated that "I was able to learn about applications that I did not know existed and then apply theory to practice in the field." It was their belief that "the different apps made the assignments more effective" and "more interactive because of the iPads."

The teacher candidates were also asked if they perceived themselves as being more prepared to be a special education teacher as a result of completing authentic assignments. Their responses again were positive (Figure 2) with the added statements that they believed they would be more prepared to implement evidence-based practices in the field.

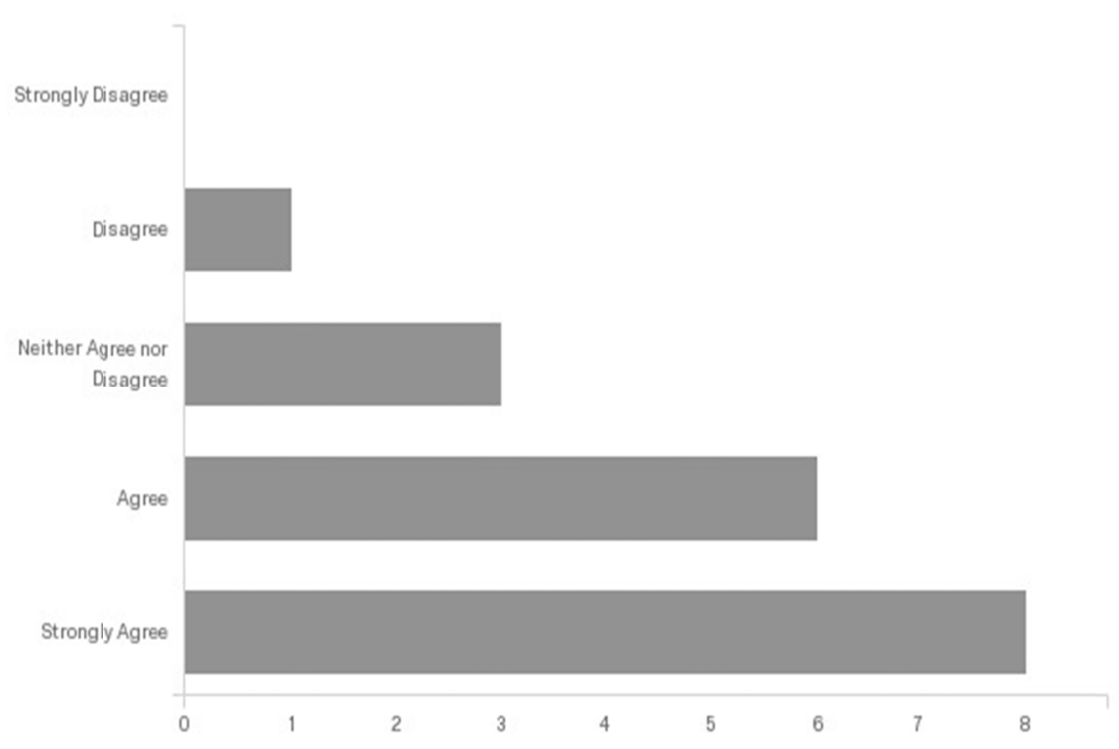

Figure 1. Did you feel as though you were more engaged with the content in class when using an iPad to complete your assignments? 


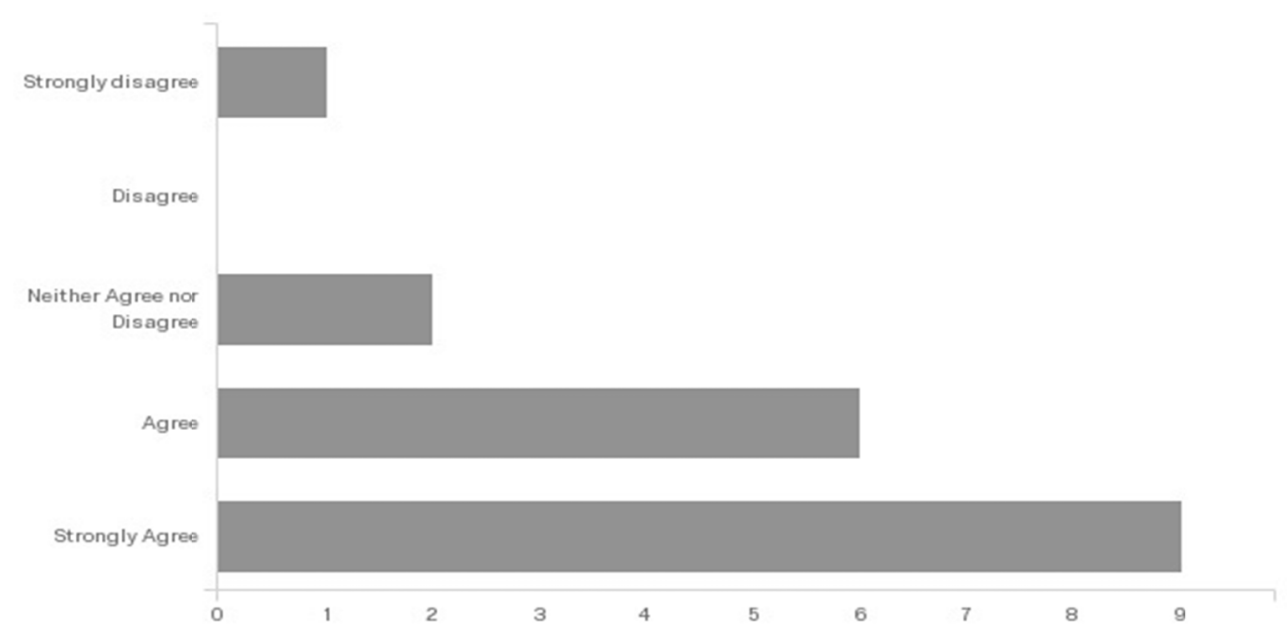

Figure 2. Do you believe that using technology for your assignments better prepares you to be a special education teacher?

\subsection{Feedback}

Although the teacher candidates were not asked specific questions in reference to the feedback that they received on their assignments, this topic was a repeated theme during the discussion in the focus group. It was in the opinions of the teacher candidates that they were able "to get feedback and instruction on how to use the apps" and that this feedback was more effective than what they received on a traditional assignment or assessment. In addition, the feedback was two dimensional in that it was presented in reference to the quality of their work and on how to implement this program in a "real-life" classroom situation.

The teacher candidates appeared to be quite concerned as to whether or not they were ready or prepared for student teaching and for their professional life beyond the higher education classroom. It was in their opinion that their confidence level was augmented by receiving feedback on authentic tasks. The benefits of completing authentic assignments were also enhanced by the opportunity to be involved in implementing this product in a learning environment and receiving feedback from their outcomes with the students in their field experience. It was discussed that this is not possible with the traditional textbook and lecture approach of learning.

\section{Discussion}

This study was a preliminary attempt to determine the efficacy or impact of changing the method of completion of assignments in the teacher preparation program of one university in order to provide the opportunity to obtain the knowledge that enables teacher candidates to make professionally sound and morally ethical and responsible judgments when developing and implementing the long and short term goals of their students. A primary goal of special education teacher preparation programs should be to ensure that their teacher candidates have the pedagogical knowledge and experience to develop and implement individualized programs for individuals with disabilities. The National Council for Accreditation of Teacher Education (2010) states that "prospective teachers must be prepared to become expert practitioners who know how to use the knowledge of their profession to advance student learning and how to build their professional knowledge through practice" (p. 2). Programs that incorporate project-based courses that emphasize technology integration strategies and authentic assignments prepare our future teachers for the realities of the special education classroom and provide ease of transferring knowledge to the community of practice.

Teacher education has evolved to include simulated learning through authentic strategies. According to Brownell, Sindelar, and Kiely (2010), special education teachers must have the ability to provide intensive, explicit instruction and must be knowledgeable of evidence based intervention strategies and assessments. They also must have the confidence that they have the ability to make decisions that will produce positive outcomes from their students and to adapt to their educational needs and requirements. According to Vernon-Dotson, Floyd, Dukes, and Darling (2014), "teacher education makes a difference" and "teacher education makes a difference in teacher candidate perception of their preparedness" (p. 36). 


\section{Limitations}

It is acknowledged that there were some limitations of this study. First, our teacher candidates were all of the same gender and represented one university preparation program. Therefore, findings may not be generalizable to other teacher candidate preparation programs. Lastly, this study included the modification of two assignments and using only one type of surface tablet. This could be broadened to include the implementation of additional assignments in the field as well as a mixture of the type of digital tool.

\section{Recommendations for Future Study}

In order to continue this study, replication for accuracy of results would be recommended in a similar institution of higher education. It has been suggested that participants should be random in selection in order to improve the validity of the study.

\section{References}

Bogdan, R. C., \& Biklen, S. K. (2007). Qualitative research for education: An introduction to theory and methods ( $5^{\text {th }}$ ed.). Boston, MA: Pearson Education, Inc.

Brenner, M. (2006). Interviewing in educational research. In J. L. Green, G. Camilli, \& P. B. Elmore (Eds.), Handbook of complementary methods in education research (pp. 357-370). Mahwah, NJ: Lawrence Erlbaum Associates, Inc.

Brinkmann, S., \& Kvale, S. (2015). Interviews: Learning the craft of qualitative research interviewing ( $3^{\text {rd }}$ ed.). Los Angeles, CA: Sage.

Brownell, M.T., Sindelar, P. T., Kiely, M. T., \& Danielson, L. C. (2010). Special education teacher quality and preparation: Exposing foundations, constructing a new model. Exceptional Children, 76(3), 357-377. http://dx.doi.org/10.1177/001440291007600307

Darling-Hammond, L., Ancess, J., \& Falk, B. (1995). Authentic assessment in action: Studies of schools and students at work. New York, NY: Teachers College Press.

Individuals with Disabilities Education Act, Amendments of 2004, P.L. 108-446. 20 U.S.C. 1400.

Iverson, H. L., Lewis, M. A., \& Talbot, R. M. (2008). Building a framework for determining the authenticity of instructional tasks within teacher education programs. Teaching and Teacher Education, 24, 290-302. http://dx.doi.org/10.1016/j.tate.2007.09.003

Krathwohl, D. R. (2009). Methods of educational and social science research: The logic of methods ( $3^{\text {rd }}$ ed.). Long Grove, IL: Waveland Press, Inc.

Laarhoven, T. V., \& Conderman, G. (2011). Integrating assistive technology into special education teacher preparation programs. Journal of Technology and Teacher Education, 19(4), 473-497.

Morrier, M. J., Hess, K. L., \& Heflin, J. L. (2011). Teacher training for implementation of teaching strategies for students with autism spectrum disorders. Teacher Education and Special Education, 34(2), 119-132. http://dx.doi.org/10.1177/0888406410376660

National Council for Accreditation of Teacher Education, Blue Ribbon Panel on Clinical Preparation and Partnerships for Improved Student Learning. (2010, November). Transforming teacher education through clinical practice: A national strategy to prepare effective teachers. Retrieved from $\mathrm{http}: / /$ www.ncate.org/LinkClick.aspx?fileticket=zzeiB1OoqPk\%3d\&tabid=715

Newmann, F. M., Secada, W., \& Wehlage, G. G. (1995). Authentic assessment tasks. In a guide to authentic instruction and assessment: Vision, standards, and scoring. Madison, WI: WCER.

Ottenbreit-Leftwich, A. T., Brush, T. A., Strycker, J., Gronseth, S., Roman, T., Abaci, S., ... Plucker, J. (2012). Preparation versus practice: How do teacher education programs and practicing teachers align in their use of technology to support teaching and learning? Computers \& Education, 59, 399-411.

Vannatta, R. A., \& Beyerbach, B. (2000). Facilitating a constructivist vison of technology integration among education faculty and preservice teachers. Journal of Research on Computing in Education, 33(2), 132-148.

Vernon-Dotson, L. J., Floyd, L. O., Dukes, C., \& Darling, S. M. (2014). Course delivery: Keystones of effective special education teacher preparation. Teacher Education and Special Education, 37(1), 34-50. http://dx.doi.org/10.1177/0888406413507728 
Wiggins, G. (1999). Assessing student performance: Exploring the purpose and limits of testing. San Francisco, CA: Jossey-Bass Publishers.

Zhao, Y. (2003). Introduction. In Y. Zhao (Ed.), What should teachers know about technology?: Perspectives and practices (pp. xiii-xviii), Greenwich, CT.

\section{Appendices}

Appendix 1. Authentic Assignment Follow-up Survey

Directions: This survey is a follow-up to the iPad pilot conducted in the first half of this semester. It is intended to better understand how the iPad was used over the term. We are asking for identifying information in this survey so that we can match this with your other study records throughout the course, however, your opinions, beliefs, and responses to this survey will in no way impact your standing or performance in the class and will not be shared with your professor until after the term is over. Any identifying information requested in this survey will be known to researchers only; any information released from this survey to the public will be stripped of identifying information.

Q1 Your iPad experience: To what extent do you agree/disagree with the following statements?

\begin{tabular}{|c|c|c|c|c|c|}
\hline & $\begin{array}{c}\text { Strongly } \\
\text { Disagree (1) }\end{array}$ & Disagree (2) & $\begin{array}{l}\text { Neither Agree } \\
\text { nor Disagree (3) }\end{array}$ & Agree (4) & $\begin{array}{c}\text { Strongly Agree } \\
\text { (5) }\end{array}$ \\
\hline $\begin{array}{l}\text { The iPad } \\
\text { encourages } \\
\text { exploration of } \\
\text { additional } \\
\text { course topics (1) }\end{array}$ & O & O & O & O & $\mathrm{O}$ \\
\hline $\begin{array}{l}\text { The iPad helps } \\
\text { me more } \\
\text { effectively } \\
\text { manage my } \\
\text { time. (2) }\end{array}$ & O & O & $\mathrm{O}$ & O & $\mathrm{O}$ \\
\hline $\begin{array}{l}\text { I think the iPad } \\
\text { enhanced the } \\
\text { learning } \\
\text { experience of } \\
\text { this course. (3) }\end{array}$ & $\mathrm{O}$ & O & $\mathrm{O}$ & O & $\mathrm{O}$ \\
\hline $\begin{array}{l}\text { The iPad } \\
\text { provides } \\
\text { functions/tools } \\
\text { that are not } \\
\text { possible with a } \\
\text { traditional } \\
\text { textbook or } \\
\text { another device. } \\
\text { (4) }\end{array}$ & O & O & O & O & O \\
\hline $\begin{array}{c}\text { The iPad lacks } \\
\text { important } \\
\text { functions/tools } \\
\text { that are available } \\
\text { with a }\end{array}$ & O & $\mathrm{O}$ & O & 0 & O \\
\hline
\end{tabular}




\begin{tabular}{|c|c|c|c|c|c|}
\hline $\begin{array}{c}\text { traditional } \\
\text { textbook or } \\
\text { other device. (5) } \\
\text { I think I am } \\
\text { learning more } \\
\text { about this course } \\
\text { as a result of } \\
\text { using the iPad. } \\
\text { (6) }\end{array}$ & 0 & 0 & 0 & 0 & 0 \\
\hline $\begin{array}{l}\text { Using the iPad } \\
\text { makes this } \\
\text { course more } \\
\text { interesting. ( } 7 \text { ) }\end{array}$ & 0 & 0 & 0 & 0 & 0 \\
\hline $\begin{array}{l}\text { I can learn more } \\
\text { in any class by } \\
\text { using the iPad. } \\
\text { (8) }\end{array}$ & 0 & 0 & 0 & 0 & 0 \\
\hline $\begin{array}{l}\text { I would opt out } \\
\text { of this course for } \\
\text { an identical } \\
\text { course that did, } \\
\text { not include the } \\
\text { iPad. (9) }\end{array}$ & 0 & 0 & 0 & 0 & 0 \\
\hline $\begin{array}{l}\text { The iPad } \\
\text { enhanced my } \\
\text { experience in the } \\
\text { classroom. (10) }\end{array}$ & 0 & 0 & 0 & 0 & 0 \\
\hline $\begin{array}{l}\text { Using the iPad } \\
\text { in class } \\
\text { encouraged me } \\
\text { to interact more } \\
\text { than I normally } \\
\text { would with my } \\
\text { classmates. (11) }\end{array}$ & 0 & 0 & 0 & 0 & 0 \\
\hline $\begin{array}{l}\text { Using the iPad } \\
\text { in class } \\
\text { encouraged me } \\
\text { to use online } \\
\text { course materials } \\
\text { more than I } \\
\text { usually would } \\
\text { for my class }(12)\end{array}$ & 0 & 0 & 0 & 0 & 0 \\
\hline $\begin{array}{l}\text { The iPad was } \\
\text { effective in this } \\
\text { course. (13) }\end{array}$ & 0 & 0 & 0 & 0 & 0 \\
\hline
\end{tabular}


Q2 Please provide 1 example of how the iPad was used effectively in this course.

Q3 Please provide 1 example of how the iPad was used ineffectively in this course.

Q4 Please provide 1 example of how the iPad could have been used more effectively in this course.

Q5 How did you use the iPad for this course?

Q6 How difficult is going to be to give up your iPad?

O Very Easy (1)

O Easy (2)

Somewhat Easy (3)

O Neutral (4)

O Somewhat Difficult (5)

Difficult (6)

Very Difficult (7)

Q7 Please comment on your answer to the previous question.

Q8 What benefits do you see from using an iPad for students like yourself?

Q9 What type of computer do you use?

O Mac (1)

O PC (2)

Both a Mac and a PC (3)

None (4)

Other (5)

Q10 Is the computer you use the most in the previous question:

O Desktop (0)

O Laptop (1)

Q11 Before this course I had used an iPad:

O not at all (1)

a few times (2)

O sometimes (3)

often (4)

O always (5)

Q12 Do you own your own iPad?

O Yes (1)

No (2) 
Q13 Technology Service Center (TSC) Please answer the following questions regarding the support and service you received from the Technology Service Center (helpdesk, SC 129). TSC (check-out and return of iPads, initial setup, support)

\begin{tabular}{|c|c|c|c|c|c|}
\hline & $\begin{array}{c}\text { Strongly } \\
\text { Disagree (1) }\end{array}$ & Disagree (2) & $\begin{array}{l}\text { Neither Agree } \\
\text { nor Disagree (3) }\end{array}$ & Agree (4) & $\begin{array}{c}\text { Strongly Agree } \\
\text { (5) }\end{array}$ \\
\hline $\begin{array}{l}\text { Overall, I am } \\
\text { satisfied with } \\
\text { the service } \\
\text { provided by the } \\
\text { TSC for my } \\
\text { iPad. (1) }\end{array}$ & O & $\mathrm{O}$ & $\mathrm{O}$ & $\mathrm{O}$ & $\mathrm{O}$ \\
\hline $\begin{array}{l}\text { The TSC staff } \\
\text { had sufficient } \\
\text { knowledge to } \\
\text { resolve my } \\
\text { service request } \\
\text { regarding my } \\
\text { iPad. (2) }\end{array}$ & O & $\mathrm{O}$ & $\mathrm{O}$ & $\mathrm{O}$ & O \\
\hline $\begin{array}{l}\text { The TSC staff } \\
\text { resolved my } \\
\text { service request } \\
\text { regarding my } \\
\text { iPad in a timely } \\
\text { manner. (3) }\end{array}$ & $\mathrm{O}$ & $\mathrm{O}$ & $\mathrm{O}$ & $\mathrm{O}$ & O \\
\hline $\begin{array}{l}\text { The TSC staff } \\
\text { resolved my } \\
\text { service request } \\
\text { regarding my } \\
\text { iPad in a } \\
\text { professional } \\
\text { manner. (4) }\end{array}$ & 0 & $\mathrm{O}$ & $\mathrm{O}$ & O & $\mathrm{O}$ \\
\hline
\end{tabular}

Q14 To what extent do you agree/disagree with the following statements?

\begin{tabular}{|c|c|c|c|c|c|}
\hline & $\begin{array}{c}\text { Strong Disagree } \\
(1)\end{array}$ & Disagree (2) & $\begin{array}{c}\text { Neither Agree } \\
\text { nor Disagree (3) }\end{array}$ & Agree (4) & $\begin{array}{c}\text { Strongly Agree } \\
\text { (5) }\end{array}$ \\
\hline $\begin{array}{c}\text { Overall, } \\
\text { technology } \\
\text { makes my life } \\
\text { easier. (1) }\end{array}$ & 0 & 0 & 0 & 0 & 0 \\
$\begin{array}{c}\text { I feel I } \\
\text { accomplish } \\
\text { more in my } \\
\text { student life } \\
\text { because of } \\
\text { technology. (2) }\end{array}$ & 0 & 0 & 0 & 0 & \\
$\begin{array}{c}\text { If I don't use } \\
\text { technology for a } \\
\text { week, I feel } \\
\text { bothered or out } \\
\text { of sorts. (3) }\end{array}$ & 0 & 0 & 0 & & 0 \\
\hline
\end{tabular}


Q15 Given my overall use of all of the technologies at my disposal, on average I feel am a/an:

$\square$ expert user (1)

$\square$ advanced user (2)

口 intermediate user (3)

a basic user (4)

non-technology user (5)

Q16 Do you believe that using technology for your assignments better prepares you to be a special education teacher?

Strongly disagree (1)

O Disagree (2)

Neither Agree nor Disagree (3)

O Agree (4)

Strongly Agree (5)

Q17 Do you believe that using technology to complete your assignments in special education classes would make you more marketable as a teacher?

Strongly disagree (1)

O Disagree (2)

Neither Agree nor Disagree (3)

Agree (4)

Strongly Agree (5)

Q18 Do you believe that learning to use different apps on the iPad will assist you in getting a job?

O Strongly disagree (1)

O Disagree (2)

Neither Agree nor Disagree (3)

Agree (4)

Strongly Agree (5)

Demographic information

Q19 Please type your first and last name.

First name (1)

Last name (2)

Q20 What is your campus ID number?

Q21 What is your gender?

O Male (1)

Female (2)

O Prefer not to respond (3) 
Q22 What year are you in school?

First year (1)

Sophomore (2)

$\bigcirc$ Junior (3)

O Senior (4)

O Non-degree seeking undergraduate student (5)

O Graduate student (6)

Non-degree seeking graduate student (7)

Other (8)

Q23 What type of high school did you graduate from?

$\bigcirc$ Public (1)

Private (2)

O Charter (3)

O Homeschooled (4)

Other (5)

Q24 What type of technology (if any) were you issued by your middle school or high school? (please check all that apply)

\begin{tabular}{|c|c|c|c|c|c|c|}
\hline & $\begin{array}{l}\text { None issued } \\
\text { by my school } \\
\text { (1) }\end{array}$ & $\begin{array}{l}\text { Middle } \\
\text { School (2) }\end{array}$ & $\begin{array}{l}\text { High school } \\
\text { first year (3) }\end{array}$ & $\begin{array}{l}\text { High school } \\
\text { sophomore } \\
\text { (4) }\end{array}$ & $\begin{array}{l}\text { High school } \\
\text { junior (5) }\end{array}$ & $\begin{array}{l}\text { High school } \\
\text { senior (6) }\end{array}$ \\
\hline $\begin{array}{l}\text { Map laptop } \\
\text { (1) }\end{array}$ & $\square$ & $\square$ & $\square$ & $\square$ & $\square$ & $\square$ \\
\hline $\begin{array}{ll}\text { PC } & \text { Laptop } \\
\text { (2) } & \end{array}$ & 口 & $\square$ & $\square$ & $\square$ & $\square$ & $\square$ \\
\hline $\begin{array}{l}\text { Chromebook } \\
\text { (3) }\end{array}$ & 口 & $\square$ & $\square$ & $\square$ & $\square$ & $\square$ \\
\hline $\begin{array}{l}\text { Desktop PC } \\
\text { (4) }\end{array}$ & 口 & 口 & $\square$ & 口 & 口 & 口 \\
\hline Other PC (5) & $\square$ & $\square$ & $\square$ & $\square$ & $\square$ & $\square$ \\
\hline $\mathrm{iPad}(6)$ & $\square$ & $\square$ & $\square$ & 口 & $\square$ & $\square$ \\
\hline $\begin{array}{l}\text { Other tablet } \\
\text { (7) }\end{array}$ & $\square$ & $\square$ & $\square$ & 口 & 口 & 口 \\
\hline
\end{tabular}

Q26 Do you believe that you were more motivated to be creative when using an iPad to complete your assignments?

Strongly Disagree (1)

Disagree (2)

Neither Agree nor Disagree (3)

$\bigcirc$ Agree (4)

Strongly Agree (5) 
Q 27 Did you feel as though you were more engaged with the content in class when using an iPad to complete your assignments?

O Strongly Disagree (1)

O Disagree (2)

Neither Agree nor Disagree (3)

O Agree (4)

O Strongly Agree (5)

Appendix 2. Sample Interview Questions

You are aware that the iPads that we used in class were part of a grant from the ATDL. We wanted to have a conversation with a few students to gain an understanding of how you benefited from this technology.

1) did you feel as though you have an opportunity to put theory into practice?

2) were the assignments more authentic through the use of technology?

3) were the apps that we used intuitive or were they difficult?

4) would you recommend continuing the use of technology in the classes at SJU?

5) how would you to respond to being required to purchase your own iPad? Would you use it across classes and in your field experiences? Would it be a financial burden? 